\title{
Mexican Trans-Migrants and Their Experience on Both Sides of the Border: Intimacy and Distance Through Use of Deictic Referents
}

\author{
Keith V. Bletzer* \\ School of Human Evolution and Social Change, Arizona State University, PO BOX 87-2402, Tempe, AZ 85287-2402, \\ USA
}

\begin{abstract}
Immigration produces change, not only in sending areas and receiving areas, but most importantly, within the individual lives of men and women who migrate. For those who perform farm labor, these transformations are affected by travel and employment in agricultural work in multiple areas over time. The anchor for identity represents the life of one's past, wherever one might wish to place an emphasis in self-narrative. For the cases presented in this article, the past reflects time spent on both sides of the border between Mexico and the United States. Each side of the border becomes a place of “distant space” as well as "intimate space," dependent on one's life experiences. At times, memories are still in the process of formation among those who are recent arrivals. For others with bi-national continuity, the intimate spaces of childhood become extensions into adulthood, and for some, the memories of one side might be erased all together and intimate spaces are those experienced in the new environment. When immigrants gain the experience of bi-locality within the new environment, the bi-focal model of this side / that side becomes extended to express nostalgia and preference for places experienced as intimate space.
\end{abstract}

Keywords: Trans-migrants, agricultural workers, narrative analysis, spatial intimacies, social adversity.

As defined by William Hanks [1], deixis is the study of how "individuated objects [are placed in time and space] relative to participants in a verbal interaction.” Investigation of deictic reference provides a view of how language, as a dimension of lived space, centers "organization of communicative practice and is intelligible in relation to a sociocultural system." A main focus in research on deictic reference has been explorations of verbal utterances that depict a speaker's sense of "here" in relation to proximity of objects in space, and any significant remembrances of previous experiences, coupled with selective linguistic devices that elaborate descriptions of the historic past versus the present moment of narrated experience.

The use of "here" and "there" in reported speech encapsulates values of the cosmopolitan world to which migrants go when they cross the border, which differs from the home community left behind. Based on her work in Mexico, Hillary Parsons Dick [2] proposes that people use the distinction between there/here to criticize those who leave for the United States. Conversations she heard in her field site were her data source. When contrasted against the use of there/here appearing in taped interviews with migrants in agricultural settings outside urban areas on the East Coast, we find a different situation. Asked to provide data on worktravel, drug use and sexual relations, these migrants varied in the frequency they used the there/here distinction, which they utilized not only to contrast their living circumstances in the eastern United States with those they left behind in

*Address correspondence to this author at the School of Human Evolution and Social Change, Arizona State University, USA; Tel: 520-229-2785

E-mail: keith.bletzer@asu.edu
Mexico, but also among those with experience on both coasts, to contrast life in the western versus the eastern United States. Generally, the distinction that was used carried overtones of nostalgia for current versus past experience, longing for what they left behind, and remembrance of their distanced attachment to people who remained behind.

One interpretation for this difference in observations of the distinction between there/here relies on the use of these locus markers that serve different purposes dependent on the setting. One might use a distinction to signal a critical stance against choices made by a third party in open conversation, for example, but rely on another spatial reference to express sadness for one's family that remains in one's hometown.

Migration is a spatial-temporal process that has the potential for eventual, or immediate, economic and social transformation. Called "trans-migrants" if they cross national borders, men and women who migrate may aspire to transformations, or they may occur without the agency of someone who seeks them. Researchers note the inclination of trans-migrants to remain in contact with natal communities in home countries at the same time they are gaining a new experience and earning a livelihood in a new environment, a portion of which they may remit to family back home. Return visits to a home village can occur both regularly [3] and irregularly [4].

The idiom in which migrants describe their new life in a new environment contrasted to pre-migratory experience centers on acknowledging the border they cross into the new country. Most persons who enter the United States enter from the south, crossing the border in one of the four southwestern states. Some remain in the state they enter and some 
secure rides to other areas of the country. A majority of trans-migrants who cross this border are from Mexico, and Central America, and description of "the other side" generates what Patricia Zavella [5] calls a peripheral vision for the potential of "what might be" rather than what was left behind. Emphasis in formal narratives and everyday talk draws from a sense of bi-cultural knowledge and personal comfort with social processes that affect one on a daily basis, which together form a strategy of self-identity management through speech called "footing." One may identify with either side of the border. The way one identifies is evident in spatial references within one's narratives. "This side" (este lado) can represent life in the United States, or life that one remembers in Mexico, and "that side" (aquel lado) might represent the life one left behind, or what one imagines from a model of previous experiences in Mexico. Marilyn Davis [6] in Mexican Voices, American Dreams, for example, writes from the perspective of residence in a small Mexican town. She refers to "going and coming" of people from San Pedro, followed by their return, often years after living in the states. Understandably, she orders the sense of "here" sequentially from the viewpoint of residents who return from migration to/from the United States (she was teaching at the time in the village). Unlike Davis, Rubén Martínez [7] in Crossing Over describes the experience of migrants from a village in Michoacán, Mexico, to various locales within the states. Reinforcing what Davis observed, he writes, "The migrant trail is a loop not only in space but in time. Future lies in America, the past in Mexico," adding an evaluative comment that reflects the main idea of lived space (postulated by Hanks [1]), "The future also can be painful for a migrant in America; the distance from loved ones in the homeland can become unbearable” (p. 9).

The idiom of "two sides" of the border provides an analytic framework within which to examine the impact of preborder and post-border experiences on the lives of transmigrants. How do trans-migrants who cross national borders refer to sidedness in talk? What significance do variations have in telling us about immigrant life? Three cases were selected to represent the basic dimensions of immigrant experience within U.S. agriculture. Each case fits one of three categories into which Juan Vincent Palerm [8] places farm workers in this country: (a) those who work in farm labor as trans-migrants, constantly moving from locale to locale, and area to area, (b) those who form bi-national linkages, generally by maintaining residence on each side of the border, and (c) those who settle in one area but "sojourn" outside the area for seasonal farm work. Agricultural labor is an instructive venue for this model, since agricultural workers often experience more movement and residential instability in the new country than they did at home, or they may position themselves in one locale and work regularly. The three cases represent the range of living and working in a bi-national context of recipient and home communities (that of Roberto Sanchez), migratory life with neither single long-term residence nor employment in this country (that of Manual Suarez), and rejection of one's home community (homeland) for life in this country (that of Andre Molino).

\section{DATA AND METHODS}

The three cases selected for analysis are taken from a larger corpus of interviews with 127 men and women with experience in agricultural labor at some point in their lifetime. Most in fact were working in farm labor at the time of interview. The three men represent a general range of migrant experience in this country, and their interviews replicate aspects of the linguistic issues highlighted in the introduction to this article. To control for the influence of cultural background on linguistic performance, I selected men born in the same region of a single country. Two were born in the same province, and one in a neighboring province.

Sample recruitment for the entire sample was conducted in six sites in three states of the southeastern United States. Several persons were interviewed more than once. Interviews varied from 45 to 90 minutes for most, and two hours or more for some. All the interviewees received informed consent and were reimbursed $\$ 15$ for time (each interview). Most questions were open-ended and semi-structured questions and began each of the interview's three sections on travel-work, drug/alcohol use, and sexual experience. The order of interview questions went from general to those of greater sensitivity within each of the three components. Interviews were transcribed in the language in which they were conducted. Transcribers were native speakers of Spanish or English as a first language; all were bilingual. They were trained in transcription techniques by the author, who subsequently reviewed transcriptions against the interview tapes. ATLAS.ti was used to code interview data for analysis, and Statistical Package for the Social Sciences (SPSS) was used to organize data on sample characteristics.

The criteria for selection into the study were experience in agriculture, and current or past experience with drugs and alcohol. Some men and women were active drug users at the time of interview, or had been users in the recent past of whom. Several were currently in treatment or in recovery. Most were active in farm labor, except for a few who were receiving disability and/or recovering from work injuries. Forty-three men and two women in the sample (45/127) came to this country as trans-migrants. All interviews were conducted in Spanish, except three in English (one Latina came as a pre-teen; two men from separate Caribbean countries), and two partially in English and Spanish. Transmigrant men and women represent six countries of origin outside the United States (three from the Caribbean; three from Central America). Forty-three men came as adolescents or young adults. All 127 persons were asked about their families, whether they were in the states, another country, and whether members might be living in more than one country.

\section{GETTING TO THIS SIDE OF THE MEXICO/U.S. BORDER}

Three cases are examined in this article: Manuel Suarez was age 22 at the time of interview (unmarried); Roberto Sanchez was age 38 (married) and Andre Molina was age 40 (unmarried). Two men were born and raised in provinces of central Mexico that were indigenous in origin in the recent past (Roberto Sanchez; Manual Suarez), and one in a border area of large towns and ranchos or unincorporated rural areas (Andre Molino, age 40). As noted by Juan Gonzalez Jr. [9], many men and women, similar to Andre, Roberto and Manual, soon become dependent on farm labor for livelihood, once they arrived in the states. 
Andre came to the United States as an "emancipated teen," economically independent of his family; he worked for three months outside his home province in Mexico, before entering the states. Manuel crossed the border with an uncle and Roberto accompanied older brothers. Soon after their arrival, these two men began to remit money from the states to family members. Over the entire time he has been living in the states, Andre never sent money home to his family. His circumstances will become clearer through his narrative. Roberto was "courting" when he came to the states and he later returned to marry. He maintains a residence in Mexico where his wife and children live. Andre and Manuel never married. Thus, each man had divergent experiences since leaving their homeland, despite origins in the same region of the country (Table $\mathbf{1}$ ).

I begin with stories of border crossing and trans-migrant life, as "living narratives" of life trajectory [10]. I follow with a blended linguistic and ethnographic analysis in presenting cases. Speech forms on which I focus include locative references in Spanish to talk about "there" as a place other than one's present location, whether or not one "knows" the place. That is, one can reference a place without having been physically present. Three choices exist: allá to refer to "distant space," allí to refer to indeterminate space, and ahí to refer to what I call "intimate space" owing to social proximity and/or emotional closeness. As I will show in examples from all three cases, choice of locative reference reflects an evaluative assessment of the side of the border that one is describing. A locative reference marks the domain of narrative action, usually by facilitating a shift from past as the time of the event that one experienced to narrative space at the present moment of the story told "here and now" [11]. Distant space and the use of past tense set the stage for a narrative, framing it through a distance locative (e.g., "there in my homeland") as a moment that occurred in historic time [1]. Once a story is located temporally and spatially, the speaker can move to present tense and might even include locative references that suggest spatial and/or socialemotional proximity. Hence, I use the term "intimate space" to refer to spatial references inside the story world, and "distant space" to demarcate personal experiences outside the story world of past remembrance.

\section{MANUAL SUAREZ}

Manual, the youngest and most recent arrival of the three, had no fixed residence in any one state of this country. He relied on family members for residence, occasionally living with his uncle or father, and occasionally with paternal cousins. He often depended on information where work could be found or a place to live was available from men whom he met "on the season." He went from a childhood and part of his adolescence in rural Mexico to migrant labor as an older adolescent in four eastern states, and three states of the West and Northwest.

My father already has experience here (aqui). He has been here since, well, how old am I? Since I was a baby, he's been coming to the states. He is familiar with many places (conoce muchas partes). He took us there (nos llevaba ahi), but to us-like he too was a drinker (un borra-

Table 1. Binational Linkages, Migratory Residence

\begin{tabular}{|c|c|c|}
\hline Roberto, Age 38 & Manual, Age 22 & Andre, Age 40 \\
\hline $17 \mathrm{yr}$ lived in village & 16yr lived in village & 6yr rancho, 8yr small city \\
\hline Age 17 enter U.S. & Age 16 enter U.S. & Age 14 enter U.S. \\
\hline Occasional return home & Returned home once & Never returned home \\
\hline West Coast work history & Migratory work history & Varied work history \\
\hline 4 companies over 17 yrs & seasonal, migratory & varied rural and urban \\
\hline West coast residence & Scattered residence & Various locales \\
\hline Housing: 3yr; 7yr; 7yr & by season NW, W, NE & 11yr rural (many) \\
\hline \multirow[t]{2}{*}{ Housing: 1yr; 1yr; 1yr } & 1.5yr with father & 13yr same rural town \\
\hline & 8mos with cousins & \\
\hline Father alive (Mexico) & Father alive (Mexico) & Father alive (Mexico) \\
\hline Mother deceased (Mexico) & Mother ill (Mexico) & Mother alive (Mexico) \\
\hline 2 brothers in United States & 1 brother in Mexico & 3 brothers in Mexico \\
\hline 1 brother, 2 sisters Mexico & 3 sisters in Mexico & 1 sister in Mexico \\
\hline
\end{tabular}


cho también). He would arrive some place, work for a while and as soon as he was drinking, they'd chase him out (lo corrían). He knew a lot of contractors (patrones), some of them-a few accepted him the way he was, but others didn't. That's the way that I came to know what's there, through my dad and uncles...

Beginning his interview with an overview of his life, Manual uses a locative reference (aqui) from a perspective on this side of the border in the United States (action verb, "coming," centers one "here"), before adjusting his footing to talk about the States from the other side of the border, where the "USA" becomes ahí "intimate there" ("he took us"). Manual's father came to this country as a migrant, which encouraged his son to come to the states. He seeks to remember his father, as he would like for him to be, not like he recognizes he is, when he alters talk in mid-sentence ("but to us-like, he too was a drinker" and "some of them-a few accepted him the way he was"). Manual's portrayal of his father several years after they had reunited on this side of the border sets the stage as a preface for a description of life in the states, which becomes his own self-portrait. As we learn from his narrative, Manual and his cousins drank in this country, which was heavily at times (like his father). Manual sometimes left farm labor crews when dissatisfied with the work, which is the inverse of his father who generally was "chased away."

Manual provides two stories of border crossing. In the first, he describes the trip at age 16 with his uncle, which was his first time to the states, as they crossed the Mexico/U.S. border with a coyote (trafficker) and then rode with a driver who took them by van to the northwestern region of the United States. The first story follows, below:

When I came from Mexico, I came with the intention of finding my father. He spent eight years without returning to Mexico. When I came here (pa'cá) five years ago, I found him. At that time, I didn't drink. I came, suffering much from the crossing. I remembered my mother, my brothers and sisters in Mexico...

Manual continues his border crossing story, telling how he was warned to ration water; how the group drank from cattle troughs and took shade behind small plants in the daytime; how they arrived with blisters on their feet in Arizona and were lodged in "safe houses" (clandestine sites to hide undocumented arrivals), where they paid a travel fee to a man with "papers" (one already documented). At one point, the coyote has the group hide in a grove of orange trees near a large city, as La Migra (border patrol) searched the area. Manual uses ahí "intimate there" throughout his narrative. When the group entered the outskirts of the large city in Arizona, for example, they hid near a canal to eat melons and watermelons they stole from nearby fields: "hidden away, to eat melons intimate-there, and to steal watermelons intimatethere from the fields" (escondidos, a comer melones, ahí, y a robar sandias ahí de los files). He accentuates his experience by repetitive use of ahí "intimate there" in the same sentence.

The second story that Manual tells about crossing the border describes his return to the states. After working almost two years in the states, Manual returns to Mexico with his father, whom he found in the Southeast. This story contains evaluative comments on his prior migratory experience that convince Manual to return to the states.

\{You returned to Mexico?\} Yeah. ((inhale)) I was like, "How will I be?" [pause] Then I told myself, "Oh well" (No pos). I got to thinking that I'd come back to the states (de irme pa'acá otra vez). I told myself I wouldn't return (no iba a volver). I spent a year and a half here (aqui); I told myself I'd never return (no iba volver). I don't know what I was thinking. I grabbed my stuff and told my father and mother, "I'm going." "Where?" they asked. "I'm going across (voy por a'i)," I told them (les dije) "to return [there] again” (de y'irme pa'cá otra vez). "So you are going. Whatcha gonna do?”

Through language, his story expresses movement across the border. The phrase, irme pa'acá, mixes an action verb "to go" (irme) with "toward here" (pa'acá) where "acá" implies movement toward an object, place, or person. Manual starts from inside the border in Mexico identified by the year-and-a-half he was living at home [note use of "here" (aqui)] when he tells his parents he plans "to go" (irme) and ends his story on this side of the border (pa'aca) in the states. From the perspective of physical presence in Mexico correct usage would be irme pa'allá ("go there") and/or venirme pa'acá ("come here”). But in Manual’s description his departure from Mexico mixes the two sides of "crossing the border," where actions of going and coming merge into a single process. As a relatively new arrival in the states (six total years - he returned to visit Mexico after four years in the states), he was sorting through his experience of life in two countries at the time of his interview.

\section{ROBERTO SANCHEZ}

When he left his hometown, Roberto was "courting." He married as an older adolescent on a return trip, but has spent most his life in this country. He lived for 18 years in a West Coast recipient community comprising men and women of his hometown and surrounding area, before moving to an East Coast daughter community (relocated 'recipient community') where he lived for three years. He maintains a residence in Mexico for his wife and children. His residence in the states has regularly been in the same site. He has no experience of internal migration inside his home country or the states, except for one season in grapes in an adjacent county to where he was living on the West Coast. Roberto does not preface his life story in the same way as Manual. Instead, he compares West Coast with East Coast and his home village throughout the interview, referencing life "there" with life "here" on the East Coast, the most recent place that he has lived. A few minutes after starting to describe what he remembers, he uses allá "distant there" to tell the listener about his hometown. When he talks about cost of living in Mexico, he uses a "distant there" for each item he identifies, followed by describing his family and the homestead of close but separate houses for each sibling and respective family, where he begins the consistent use of "intimate there" (ahi).

There (allá) we pay no water; there (allá) we don’t pay rent; there (allá); the only thing is just pay light... My whole family is there (ahí está toda la familia). My old- 
est sister gave a room to my father to live there (ahî) together with her family. My other sister doesn't live there with us (ahí con nosotros). She went ((rub eyes)) to live there (allá) with in-laws. They gave her a place there (allá) with her spouse; she lives there (allá). All the rest, we live there (ahî) together... Yes, family land is pretty there (por allá). Each one has a share (su parte). And my share is empty... "Now, I'm not going to live there," I tell my family, "I'm here, where I have a house, and I go to Alcoholics Anonymous." ("Ya 'horita ya no voy a vivir allá," le'igo, "Estoy aquí en una casa, y aquí voy a Doble A")... There in my homeland, Mexico (allá en mi tierra de México), when I left home (tierra), I left my fiancé.

In this excerpt, Roberto stages his description of family lands in his home village, using the form allá "distant there." He shifts to ahí "intimate there" to describe his siblings all of them still living, one sister who provided their father a room, and his family's request that he return more often. He distinguishes property on which five of six siblings live (ahí "intimate there") with the locale where an older sister went to live (alla "distant there") with her husband. Since her current experience is infrequent with that of the family of orientation, she is described separately from the residence-based family unit with the locative reference, allá "distant there," which occurs amidst use of ahí "intimate space" for his family of orientation who continue to live together. In one sense, moving from the West Coast to the East Coast is the most recent "border crossing" he has experienced.

Roberto does not provide a border-crossing story or mention which of his older brothers actually planned the trip the first time he came to the states, or for any of the return trips to visit his family. Instead, he spent time in three interviews exploring and comparing aspects of life on the West Coast with that of the East Coast, and life he remembers as a young boy in Mexico. He and his siblings were close and they shared many similar experiences in growing up.

\section{ANDRE MOLINO}

A third variation on living outside the United States is presented by Andre Molino. He lacked continuing binational ties with his hometown and has spent time outside locations where persons from his home village were living in the states. He worked for 13 years each on the West and East Coast, respectively. He had migratory work experience "on the season" in three states of the Northwest when he was based on the West Coast, which is a general pattern of work that has been reported among migrant workers based in California [11] and later in the Midwest and adjoining eastern states, when he was based on the East Coast. He characterizes his early years in Mexico, as a life of suffering. Unlike extensive use by Roberto and modified use by Manuel, he does not introduce early remembrances of his life by using allá "distant there." Instead, the one time he uses "there" is not to describe family or the rancho where they lived before moving to a city, but time he spent as a young boy in bars, watching his mother. For this, he uses indefinite "there," allí, rather than the more definite allá "distant there" or ahí "intimate there."
We all suffered... I couldn't say nothing. My brothers were bothersome. The oldest messed with me (me ching'ba). Wouldn't leave me alone... Father took us to bars. Age 7, 8 or 11, 12, I'd watch the women who were sex workers there (alli) in the cantina... See, my mom was a bar prostitute (andaba carajilla). ((probe question clarifies meaning)) If I spoke out or said anything, I got hit with a belt. So I watched her....

Andre emphasizes a childhood of suffering: he mentions hunger and neglect; time in cantinas with his mother, who was a sex worker; an older brother who constantly bothered him; indifference from his extended family, at least one of whom Andre characterizes as “mean.” At age seven, Andre's parents separated. His father worked as a brick mason (abañil) and he often traveled to distant jobs. His mother was a sex worker, whom he describes with the euphemism, andaba carajilla (probe question clarifies he means "hooker"). He describes his father treating his children nicely (Era buena gente "He was a good person"), taking them to cantinas, where Andre remembers how he "watched the women." He never identifies his mother as a sex worker, and he never refers to sex work for women in Mexican bars or local women who provide sexual services where he currently lives. He uses an "indeterminate there" (alli) for the bars in Mexico, which is the first and only time he uses a spatial referent for his life in Mexico. He never uses a locative referent for his family. Through silence he has disowned them. In a passage not shown here, he uses tristiando (drinking sadness) and bailando (dancing) to characterize the activities of men and women in bars in Mexico, where he spent considerable time. His mother worked in the bars as a cantinera which is defined by Martínez [7] as "part bartender, part taxi dancer" (p. 309) compared to a more direct definition by Fernández-Esquer [12] as "sex worker.”

Having described growing up, Andre tells how he came to leave home. From the border province he went to an interior province (internal migration), where he found seasonal work in the tomato harvest. He met someone coming to the states, who, when he was asked, agreed to take him across the border, at no charge, other than the cost of transportation.

When I was fourteen ((voice fade)) I left. If birds (pajaritos) want freedom, they go. I never went back (nunca volví pa' atrás)... I spent three months in [interior province]. There was a young man around twenty-six; he was coming to the states (venía pa'acá a los estados). It occurred to me, to ask him if he was coming (si él venía pa'acá)?, if could he bring me (si él me puede traer)? "I don't know if you'll charge me?" He says, "No, muchacho, if you want, get ready, and we'll go. Get together food for the trip.” How luck touches one... I was the youngest (más chavalillo) in the group.

Once across the border, the main group divided into two groups; Andre and seven others went to California. No references in his narrative to life in Mexico incorporate any form of the locator "there," until the final story in his narrative, and no use of past rather than present tense appears in other passages on life in Mexico (not shown here). Telling the story of his decision to emigrate from Mexico to the states, he includes the present tense, and he includes acá, a locative 
reference that implies movement toward an object, goal or person. For Andre, the goal was to enter the United States, as much as it was his desire to leave his family to start his own life.

\section{LIFE ON THIS SIDE OF THE MEXICO/U.S. BORDER}

In contrast to Andre, who describes suffering in his homeland rather than in the states, Roberto and Manual tell tales of suffering that take place on this side of the border. For Manual who was a recent arrival, suffering permeates most all his experience in the states. For Roberto, suffering takes on a spatial dimension in having moved from the West Coast to the East Coast.

\section{MANUEL SUAREZ}

In coming to the states, Manual fulfilled his wish to find his father. In describing this encounter, he skips the portion of his story that would explain how he acquired information on where he could find his father, the five-day trip by truck that he took from the Northwest to the Southeast and the friend he met on the trip. Instead, the story begins with the encounter:

There it was that I found him. (Ahí estaba ahí lo hallé) When I got there--he didn't know me ((inhale)) ((surprise)) he didn't [even] know me and, and later I just said "forget it."

Manual prefaces this story, emphasizing his father not recognizing him and establishing the space of the encounter as "intimate there" (ahí repeated in the opening sentence). From prior information, the listener recognizes that Manual has not seen his father in eight years. He uses ahí in a sentence that moves from past (pregunté) to present tense (dice), which thus completes the linguistic process of bringing the listener into the narrative world of reunion with his father.

So, I asked them (les pregunté ahî), they tell me (me dicen). "Do you know where a man named Felipe lives?" [to interviewer] My father's name is Felipe; his name is Felipe Suarez. [story] One says, "Yeh, in that traila (aquella traila)," he says (dice), "They booted the others out (los corrieron). I believe one gent stayed there (ahí se quedó), by himself." I ask, "But you're sure his name is Felipe.” He says, "Sure.” He said to me, "He's a short fellow" (chaparrito). "Yeh, that's him."

Despite a preface that is common throughout his narrative Manual moves quickly into the story of reunion with his father. This is unusual, as Manual typically crafted rather than truncated his stories. Another stylistic variation in this story of encounter is the use of reported speech that often contains an understood reference that he is asking about his father's whereabouts ("them," les). Manual quickly became an insider to this world, where one's appearance and attire identify one as a farm worker, and he readily secures the assistance he seeks. Manual is surprised to find his father the morning of his arrival (near dawn), as he continues his story.

It was there (ahí mismo) that we arrived in that town. It was like a trailer park. I asked, "In this trailer?" and one told me, "He's in this one (está en esta). Distance was no more than from there to here (de ahí a aquí asî) ((mo- tions an imaginary distance, right hand, left hand, on table)). "I didn't know he was there" (ahî). It was fortune [just] to get there. And so I got there, right?

His surprise is surpassed by credulity upon seeing his father for the first time in eight years. The family reunion between father and son follows an unexpected trajectory, when aspects of the living circumstances of his father gradually become clear to him.

I knew him, once I was there. He had ((hands move circular around an imaginary bed)) a ring of beer cans (botellerio) around his bed. He was on one side of the bed, asleep like this ((moves his head to one side)). I believe that he fell asleep around 6:00 in the morning. Everyone [men] was outside there (allá afuera), ready to go to work. It made me very sad to see him there (ahi) like that. Like he was there (ahi); it made me so sad to see him cast aside (tirado, “discarded like trash”), surrounded by beer bottles. I felt quite sad and alone (me sentí pues triste y solo). I was with a friend whom I met in the truck.

Manual's story of how he encountered his father is accentuated by gestures and he provides a context to his father's lifestyle, as he indicates that men were waiting outside to go to work, a common sight in migrant-occupied trailer parks in the southern United States. Drawing on the hindsight of several years in farm labor at the time of his interview (not the time of encounter), plus acquainted with his father's drinking behavior, Manual says his father was up all night and fell asleep at dawn (6:00 AM). He inserts an evaluative comment at this point in his narrative, asking himself and the listener, "What if something was to happen to me here (aquî). May the Good Lord never will it! Who will notify my next of kin (avisar de mi)? Who will know where I was?" In Spanish he stretches the final syllable of "here," before showing self-awareness of his solitude away from home. He continues with his story, this time using an "indeterminate there."

I saw my father there (alli) like that and, I asked him (le dije), "Your name is Felipe?" (¿Se llama Usted Felipe?) He replied (dijo), "Yes." He says, "Who are you?" (¿Quién eres tu?) I said (dije), "So, I came to find a man named Felipe, I believe (creo) he is my father."

At this point in his story, Manual lowers the register of his voice. He says,

“He just stared at me” (**nomás se me quedaba viendo $\left.a i^{* *}\right)$. He said (dijo), "But who are you? (¿Pero quién eres tu?) What's your name?" I told him, "My name is Manual," I told him, "My name is Manual Suarez. My mother's name is Socorro, my mother's name is Socorro and I am from [village]. My home village (pueblo), that's were we live. It's called [village], I am from [village] and-I came looking for a man named Felipe.”

I use double asterisk $(* *)$ to mark the tone of this phrase, which indicates an overarching sense of desolation that continued to accompany Manual, which became evident throughout his interview. He repeats the clause he used to identify his father (Felipe Suarez) giving his first then full name. He states both parent names, thus giving his father an opportunity to complete the pair. 
Now he was awake (ya que se despierta), all sleepy (dormido) and hung over (borracho). He hugs me when he sees me (me abraza que me ve). He hugged me and began to cry (me abrazó y empezó a llorar). I told him, "No," I said, “Don't cry” (**no llore**), I told him, "So, it's all right” ( $p$ 's ya). I told him, "Here I am,” I told him, "I came to find you" (Vine a buscarlo).

The joyous reunion he anticipates never occurred. Instead, Manual comforts his father, which I mark with double asterisk to indicate Manuel's resignation at the circumstances of the encounter. He uses a soft speech register, and elongates "No," as a means of re-assurance. Adults comforting adults is not unknown in Latino society. Tomás Rivera [13], for example, in Y No Se Lo Tragó la Tierra tells the story of a mother who went shopping for gifts, but became confused (her husband worked 18-hour shifts as dishwasher) and was brought home by her compadre. He offered to buy gifts for her, as he tells her, “Don't cry, don't cry” (Ya no llores, ya no llores). Irony in the narrative is that Manual is a minor. The person he is comforting is an adult and also his father, which is a reversal of the expectation of the parent comforting a child. Later in their relationship, Manual, "encouraged” by alcohol, would confront his father.

And I used to tell my dad (le decía) ((nervous)), “No, you talk, you work, you control, because you have your children there?" (No p's, uste' hable y uste' trabaje y usted mande, porque usted tiene a sus hijos allá?)... When I went on drinking, he never said anything. "You've never told me anything, except "Speak to your mother, she wants to hear from you (oirte hablar)'." "Not me,” I told him, "You need to speak to her, not me." All I've done in my life has been mistakes, because of [my / his] alcoholism (por causa del alcoholismo)... Who knows what I would tell my dad when I was drinking. Now, he doesn't drink at all ((exhales)) He's back in Mexico. He hasn't drank (no ha tomado nada).

In this passage, Manual clarifies frustration he experienced with the father-son relationship. Similar to comforting his father, by telling him "Don't cry," when they re-united, Manual told his father that appropriate behavior for a husband was to write to his wife. Manual refers to his father's children allá "distant there," which suggests a nostalgic if not disappointed view of life in Mexico when his father was absent owing to his life in the states. Thus, the son shows concern for a drinking father and that he cared for him, but the father neglects his drinking son.

\section{ROBERTO SANCHEZ}

Roberto uses "there" and "here" to contrast the West Coast, compared to his East Coast experience, and his recent time on the East Coast is contrasted with his life in Mexico. He moves among all three locales in the following excerpt.

Here (aqui) we live at the edge of town (afuera); there (allá) on the West Coast we live right in the center of town... In the park by our house [México], people go to play volleyball, soccer. They sell tacos, menudo, pozole [all Mexican dishes]; they sell birria [barbecued goat's meat]... It's like my brother's place [East Coast]. People gather on Friday, Saturday, Sunday. They know each other from there, the town [Mexico] where I live (puro conocido de allá, del pueblo, donde yo vivo). We get together there (ahî) to play dominoes, cards, soccer, volleyball. They play in a little park, ((inhale)) when it's afternoon. Here where my brothers live (acá donde mis hermanos), it's whole 'nother scene there (ahí se está otra rueda), throwing dice, betting five, ten, twenty, thirty, even fifty dollars. Later, everyone arrives with beer, all from there where I come from California (allá 'onde vengo de California). We're all buddies (puro conocidos). They tell me, "Go get a beer." I say, "No, not right now" (No, 'horita no quiero). They say, "So, when did you arrive, why don't you visit us.” I tell 'em, "I don't know how to get where (pa'acá) I'm now staying, I don't know anything here" (yo aquí no conozco nada). Others tell me, "Come by the house." Some lived there (allá) in [town], others lived here (aquî) in [town].

In this passage Roberto is comparing a hometown park in Mexico with the park located by his brothers' residence on the East Coast. He notes obvious differences in remembered activities of Mexico, compared to gambling and "evil influences" of life on the East Coast. He builds into his narrative a bi-coastal comparison of life on each coast of this country. On the West Coast, he was able to give up drinking. On the East Coast from his report and evidenced by his enrollment in treatment, the temptations were great. Roberto uses a locative reference allá "distant there" in describing another town where Latinos live, thus indicating his as-yet inability to move about in the local area.

Like that, time was taken (así fué pasando el tiempo). Every afternoon, they'd come by. My brother would say, the oldest [same one who initiated him into drinking in México], "Want a beer?” I'd tell him, “No, right now I don't want one.” "Go on,” he says, so you can forget California,” he says ((chuckle)) [He was thinking] that we'd drink together to forget. For me, I was living there with a woman (como yo tenía una señora ahî). She was from [province]; I'd recently got together with her. Sure I drank, but not that much. One Saturday, yes; one Saturday, no. Every two weeks. I was with her four years. \{Did you drink Sundays?\} Sundays she and I went to Mass. We both worked. Weekdays, we [guys] didn't drink. That first year I was with her, I drank a little on Friday and Saturday. After that, I never touched a drop, not for two years, almost three years, until I came here (aqui) [East Coast].

To a question from the ethnographer, Roberto summarizes what life was like on the West Coast, and he contrasts that experience with more recent experience on the East Coast.

Did I drink there (allá)? When I met her? No one visited there (ahi). We'd go home, rest and smoke a cigarro outside, while my lady made supper. I'd be chugging a few beers (echando unas cervezas). They'd drink soft drinks. We'd be there talking (ahí pláticando), resting (descando), talking (pláticando), asking "How was work?” "How many strawberry flats you filled?" "How many did you?" "How many did I fill?" Passing time there (ahî). ((inhale)) I'd drink two, three, four beers, shower and eat, watch television there awhile (un rato ahî). Guys had a 
television, while she would wash dishes and clean the kitchen... Well, I'm really bad off here (aqui). It's different here (aqui) to there (allá). I stopped drinking there (allá) one year with her, struggling two years without drinking. There (allá) I never went to A.A., like I'm doing now [East Coast]. I never received anyone's advice (ni recibí un consejo de una persona). It was my decision, [I was on my own] leaving it behind, leaving it behind (y dejando y dejando)...

Roberto's contrastive description of the two coasts employs allá "distant there" for West Coast, and his remembrance of life on the West Coast is marked ahí "intimate there," which is treated like the "there" of family in Mexico that a migrant leaves behind. He nostalgically recalls how life on the West Coast had an uncomplicated routine, and drinking was not a major problem. Roberto "hung-out" with co-workers and roommates, and he had a woman who performed roles of domestic necessity (cooking, cleaning). She was the one who supported Roberto in his quest to cease drinking. When he left the West Coast, he returned her to her brothers' house, which is an indication that they separated under amiable circumstances. In his narrative the "woman" on the West Coast could be the wife or girlfriend whom a migrant leaves behind in Mexico.

\section{ANDRE MOLINO}

Andre spent 13 years in the western United States and the same amount of time in the Southeast. From his home base on the West Coast, he migrated several times for harvest work in three states of the Northwest. He held numerous jobs in and outside agriculture along the West Coast, including two years in a restaurant in an urban area where he briefly was living. From the West Coast, he came to the East Coast. For a few years he migrated regularly on-the-season.

When I was in [state] there (allá), I heard about [state]. That one could earn good money, it was pretty, that is was better than there (estaba mejor que allá). So, I came from there (allá). Never gone back there (pa' allá) to [state]. No, here (aqui) is where I've been ever since. I've never gone back to [state]... Half my life on the West Coast, half my life here (aqui)... All my life, I've worked tomatoes. I never liked working in cities... I like work in agriculture (me gusta andar en el labor). One is better off (más a gusto). One is working outdoors. One is with one's own people, Hispanos, talking, conversing, and ((emphasis)) that's why I like working in the fields (esel-porque-me-gusta-trabajar en el field).

Describing life on the West Coast that he left behind, Andre first uses allá "distant there.” This is the point he begins to describe a significant transition for himself from one coast to the other. It is as if his life in Mexico never existed, replaced, as it were, by time on the West Coast, from age 14 to 27, followed the East Coast, from age 27 to 40 . He notes the money one can earn and the beauty of the East, not unlike the young men in Mexico who hear about life in the United States and decide to cross the border and come to the states.

Andre's experience in this country goes beyond that of the immigrant who becomes very dependent on alcohol as a means of coping with life in a new environment. Andre had tried marijuana as a teenager in Mexico in the province where he went to work, after leaving home. That he initiated marijuana within a few weeks of time in a place of shortterm accommodation is atypical, since most drug use onset occurs once a farm worker has lived a year or more in a locale or home base community [14]. Andre provides a synopsis of initiation of one drug he used in the past (heroin) and those that he was using at the time of his interview (alcohol, crack, marijuana). Similar to others in my sample (Spanish and English), Andre's onset stories were truncated without much detail. Evaluative comments were commonly succinct among these interviewees, as if each had reflected in the past on the meaning of drugs and alcohol in their life.

Andre provides an account of feelings toward the family he left behind in Mexico. This particular story is longer than any account that he provided in his life story narrative. Events took place a few years before Andre's interview.

I was working at [tomato packing plant]. I look, at this-he said, "Chihuahua, Hey, Chihuahua.” He came close. I say, "Hey, friend," I say, "You (tu), where ya from? From Chihuahua, uh?” "Yes, I’m from Chihuahua.” And we began to talk, right? He says, "What part of Chihuahua are you from?" Says, "I'm from Ciudad Ese,” says, “And you, where're you from?" I say. "Rancho Nombrado," he says. ((pause)) ((softly)) I say, "Know what," says, "I'm not from Ciudad Ese," I said, "I'm from Rancho Nombrado, too. That's the same rancho where I was born." Then he says, "Listen, what family are you from?" I said, "I'm from the Molino family." "Oh, you're a Molino," he says, "Many of them I know” ((pause)), says, "Who is, where are your uncles?" I said, "Look, my dad's name is Fulano [actual term used], my uncle's name is Fulano [actual term], my uncle's name is like that” ((pause)) All my aunts, uncles, siblings and cousins I named. Then he says, "Listen, I know your uncles, I know your brother, your sister, I know your whole family,” says. "Do you know my father?” I asked him. He tells me, "Yes, I know your mother, your uncles, ((pause)) you came from the same rancho as I."

Similar to the truncated version of reunion with his father that Manual employs in asking questions to find his father, Andre follows a similar tact in the passage above, except that place of hometown residence serves as a marker of identity as these two men seek to ascertain if they share a common background. Unlike Manual's story where full names were used, Andre hides names of kin beyond his paternal male relatives. Instead, he identifies his surname which serves to encompass his nuclear family as part of a large extended family. He continues his story.

Two months later, I meet him ((pause)) he says, "Paisa," says, "Let's go, I'm going back,” says, "Let’s go.” He was going back to the border, and he invited me. Says, "Let's go." "No,” I say, "I'm staying ((pause)) when you come from there (allî), I await you here (aqui).” I say, "But please don't tell anyone, if you see my family ((voice fade)). Tell them that you know nothing, [don't say] that you saw me.” ((regular register)) I said to him, right? When he arrived, the first thing he did was, he went to see my uncles ((voice fade)), my brothers and 
sister ((pause)) When he came back here (pa'acá), I saw him outside Muñoz Tavern. I was eating ((pause)) ((voice fade)) When I saw he returned ((pause)) he says, "Paisa," he says, "I have a personal message (recauto) for you." ((very long pause)) "What news?" ((pause)) He says, "Tomorrow I'll leave it with you, tomorrow I'll bring it to you. Where can I find (mirar) you?" I say, "Well, here.”((pause)) And he says, "What time?” I say, "Well, you can find me around seven at night." "Great." Next day I waited for him at seven at night. He arrived with four letters (cuatro cartas) that came from there (allá), sent by my mom ('amá) and my dad ('apá) and brothers and sister ((pause)) I did little more (no más:) than look at one letter (miré una carta). I opened it and glanced at it (miré); I wanted to read it (dese'a leerla) ((pause)) About four, five lines into this letter, ((pause)) from my mom ('amá) was all I read. Four, five lines. Later I burned the letters. I couldn't read any more (no las alcanzé leer nada). "Everyone is [inaudible]," was all that I read (alcanzé leer); my mom ('amá) was telling me ((long pause)) "Andre, my son, I want to see you (Andre, mi'jo, quiero verte).” ((pause)) ((voice fade)) That's all I managed to read, **fue el único.** I fixed it in my memory (eso lo grabé in la mente). She says, "Andre, ((pause)) my son, I want: to see you:” (Andre, mi'jo, qui:ero verte:). I didn't read the others. I read those four lines, made a wad like this (la hice bola asî) ((rolls hand as a ball)). I lit my lighter (cerillo) and ((snaps fingers, holds imaginary flame below imaginary wad)) I burned the four letters.

Andre reveals how he experienced a good amount of emotion when he read but a few lines in the letters from his family in Mexico (all alive), some 26 years after he left home. Despite an interest to learn about his family, indicated by his willingly meeting his friend at 7:00, he is still unable to read the letters in their entirety. The listener is familiar with his story at this point in the narrative. Andre spends time developing the story. To this point he has self-presented himself as one who is controlled in his emotions and lacking in any desire to have the young man carry a message to his family. He appears to be disinterested in having his family find out he is alive. Quiet elaboration to construct events that lead to the arrival of a set of letters from his family enhances the poignant ending that he uses to conclude the story. Throughout the telling he discloses no evaluative emotion on how this encounter might have affected him.

\section{DISCUSSION}

These narratives merge stories of border crossing and labor experience with accounts of drug use by immigrant farm workers in a new environment. Less treated in the literature, drug use is common in low-wage, unskilled labor settings [15] which certainly applies to farm labor. The experiences of three immigrants show how pre-migratory lifestyles and life in this country are associated with variations in structured and coherent self-narratives [16]. Manual prefaced stories with an abstract. More than half his childhood Iwas spent in Mexico, while his father was in the states. He himself came to the states to find his father, which generated more ambiguity in his life than he expected. Roberto spent twenty years in the states while supporting his wife and children in Mexico. He neatly separated the past into "distant" and "intimate" spaces, felt social intimacy for home in Mexico, and held an intimate view of life on the West Coast, compared to recent living experience on the East Coast. Andre made little use of locative references and he rarely marked intimate space for his childhood in Mexico. Twothirds of his life spent on East Coast and West Coast he credits as his total life experience, much like immigrants feel nostalgia for a prior life experiences on "that side," while living "this side" of the Mexico/U.S. border.

Roberto was the only man among the three who experienced bi-national linkages. After leaving his home village, he spent considerable time in a 'recipient community' (West Coast) and 'daughter community' (East Coast) during life in the United States. He was unique among the three men in his consistent and frequent use of Spanish to distinguish "distant space” from more "intimate space” using Spanish locative markers. For Roberto and Manual, Mexico was "here" as anchor to one's origins and homeland. As counter-reference to the present for Roberto on the East Coast, Mexico became a "distant there" and an "intimate there" in relation to family. For Manual, Mexico was that side of the border where he once lived, and this side of the border was an opportunity to gain new experiences. Andre on the other hand did not share memories of intimate experiences with family, as did the other two men. His experience in the states, like that of Roberto, was conceived as a bi-coastal experience. Unlike Roberto, experience of two coasts was not tempered by fond childhood memories of life on the other side of the border outside the United States. Roberto expressed dissatisfaction with his current situation on the East Coast, whereas Andre had no complaints of life on either coast of the United States. Manual, as the most recent arrival, was still framing his experience as one of movement from one side to the other side of the U.S./Mexico border, whereas Roberto and Andre each with extended experience in the states framed their experience in an idiom of bi-coastal comparisons and contrasts, much like a migrant from Mexico views the two sides of the border with a bi-focal near/far lens.

Each man within his own life narrative had acquired the baggage of drug and alcohol use, which comprised considerable drinking behavior (Roberto and Manual), as well as poly-drug use (Andre). Use patterns experienced by each man were framed within the sidedness idiom [17] that each had adapted (Roberto, Manuel) or was adapting (Andre) as migrant workers in the United States. Whereas men with alcohol problems complained of their respective behaviors (Roberto and Manual), the man with extensive drug experience refrained from complaints of his current lifestyle or use patterns (Andre). Given his early childhood of neglect and parental separation, Andre was the most "disaffected" of the three from those experiences that form a self-narrative of the past. All the three men in general showed evidence of hardships through the manner that they used to narrate their experience in agricultural labor in this country.

\section{CONCLUSION}

Immigration provides the foundations of human capital for a nation-state, at the same time that the effect on individual lives varies in impact. Some persons experience the 
changes they sought in improved economic conditions, political and social freedoms, and "adventure" in a new society, all the while they struggle [7, 18, 19]. Others experience sadness and disruption from what should have been a culturally approved life trajectory in a home village, where a life experience is possible "fixed in space." Outcomes of this sadness imbue individual lives and give rise to conditions that might not have been experienced within natal communities in homelands far from new settings where immigrants seek to earn a livelihood and/or start a new life.

Despite an emphasis in the literature on migrant inclinations to maintain cultural forms from the past, such as the activist woman cited by Rubén Martínez [7] for actively doing "what she can" to bring her Mexican village to the states (p. 317), or Leon Fink's [20] study of a self-sufficient community of Guatemalan immigrants in Morgantown, West Virginia, who maintain culture in ways that vary from family to family. The preceding narratives of border crossing, adaptation to farm labor and unfortunate consequences of drug use provide a sense of identity that anchors each man in the world of social interaction [21, 22]. Despite a total 53 years in the United States, Roberto, Andre and Manuel were dependent on Spanish for daily interactions. Thus, their hope for better jobs was made difficult for them by less than a full command of the English language [23], despite the oratory skills they demonstrated in their life story narratives. Nonetheless, through a familiarity with their mother tongue, and its mastery, they were able to express general feelings on how life on each side of the border has affected them, which provides us with an improved understanding of the tenuous difficulties and hidden accomplishments for immigrants who are living and working on this side of the U.S./Mexico border.

\section{CONFLICT OF INTEREST}

The authors confirm that this article content has no conflicts of interest.

\section{ACKNOWLEDGEMENT}

None declared.

\section{REFERENCES}

[1] Hanks WF. The indexical ground of deictic reference. In: Duranti A, Goodwin C, Eds. Rethinking context: language as an interactive phenomenon. Cambridge: Cambridge University Press 1992; pp. 43-76.
[2] Parsons Dick H. Imagined lives and modern chronotypes in Mexican non-migrant discourse. Am Ethnol 2010; 37(2): 275-90.

[3] Mines R, Massey DS. Patterns of migration to the United States and from two Mexican communities. Lat Am Res Rev 1985; 20: 104-23.

[4] Palerm JV. Immigrant and migrant farmworkers in the Santa Maria Valley. In: Vélez-Ibañez CG, Sampaio A, González-Estay M, Eds. Transnational Latina/o communities: politics, processes, and cultures. Lanham, Maryland, United States: Rowman and Littlefield Publishers, Inc., 2002; pp. 247-72.

[5] Zavella P. Engendering transnationalism in food processing: peripheral vision on both sides of the U.S.-Mexico border. In: VélezIbañez CG, Sampaio A, González-Estay M, Eds. Transnational Latina/o Communities: Politics, Processes, and Cultures. Lanham, Maryland, United States: Rowman and Littlefield Publishers, Inc., 2002; pp. 225-45.

[6] Davis MP. Mexican voices, American dreams: an oral history of Mexican immigrants to the United States. New York, United States: Henry Holt and Company 1990.

[7] Martínez R. Crossing over: a Mexican family on the migrant trail. New York, United States: Metropolitan Books 2001.

[9] Gonzalez JL Jr. Mexican and Mexican American farm workers: the California agricultural industry. New York, United States: Praeger 1985.

[10] Ochs E, Capps L. Living narratives: creating lives in everyday storytelling. Cambridge, Massachusetts, United States: Harvard University Press, 2001.

[11] Palerm JV. A season in the life of a migrant farm worker in California. West J Med 1992; 157(3): 362-6.

[12] Fernández-Esquer ME. Drinking for wages: alcohol use among cantineras. J Stud Alcohol 2003; 64: 160-6.

[13] Rivera T. And the earth did not swallow him (y no se lo tragó la tierra). Houston, Texas, United States: Piñata Books, 1971.

[14] Bletzer KV. From gambits to case data. In: Naidoo L, Ed. An ethnography of global landscapes and corridors. Rijeka, Croatia, Europe: Intech-Web.org 2012; pp. 157-88.

[15] Gil T. Men of uncertainty: the social organization of day laborers in contemporary Japan. Albany, New York, United States: State University of New York Press 2001.

[16] Linde C. Life stories: the creation of coherence. New York, United States: Oxford University Press 1993.

[17] Herman D. Spatial reference in narrative domains. Text 2001; 21: 515-41.

[18] Hondagneu-Sotelo P. Gendered transformations: Mexican experiences of immigration. Berkeley, California, United States: University of California Press 1994.

[19] Mahler SJ. American dreaming: immigrant life on the margins. Princeton. New Jersey, United States: Princeton University Press 1995.

[20] Fink L. The Maya of Morgantown: work and community in the Nuevo New South. Chapel Hill, North Carolina, United States: University of North Carolina Press 2003.

[21] Singer JA. Message in a bottle: stories of men and addiction. New York, United States: Free Press 1997.

[22] Bletzer KV. Onset of substance use among transnational and domestic agricultural workers: social relations and place of initiation. Contemp Drug Probl 2003; 31(1): 89-127.

[23] Dávila A, Mora MT. English skills, earnings, and the occupational sorting of Mexican Americans along the U.S.-Mexico border. Int Migr Rev 2006; 34: 133-57. 